of the chrysalis, and then remained distended, with its forks in shape. The nature of this organ must be determined by further observations. I had sent to a friend, who is an experienced microscopist as well as entomologist, a chrysalis of interrogationis which had been dropped in glycerine at the crisis of pupation, and he writes me thus: "I have examined the preparation, which was in good condition except the separation of the chrysalis from the skin. I see what you call the two ridges, which exist also in the caterpillar and have between them the anus in both caterpillar and chrysalis. Further, I find connected with the skin the whole rectum, and a little more of the intestinal canal, drawn out in pupation. A little below I see a substance which I suppose to be your membrane, about as long as the rectum and structureless. I would suppose that the membrane belonged to the rectum and perhaps the external cover of it, if you had not written that the membrane in archippus is black. I took a caterpillar (in spirits) of this species, and opening it, found that the rectum was white, or at least light colored. One should make a section of the caterpillar of archippus just after suspension to discover where this black membrane comes from. The use and purpose of the knobs and bars in the chrysalids is doubtless this: in these organs are built up and developed the anal appendages of the imago."

September, 1878 .

\title{
NEW N. AMERICAN LEPIDOPTERA, WITH NOTES ON A
} FEW LIT'TLE KNOWN.

BY A. R, GRO'L'E, A. M.,

Director of the Museum, Buffalo Society Natural Sciences.

Daremma catalpae.

Sphinx catalpae Boisd., pl. 2, figs. 5, 2 (1874).

This species is represented in the Collection of Mr. E. L. Graef by an example from Florida. It is smaller and darker than $D$. undulosa or $D$. Hageni, of a uniform butternut or olive brown tint. 


\section{Emydia ampla, n. s.}

\&. Wings large, body linear, slight. Eyes naked; palpi exceeding the front; maxillæ weak. Antennæ ( $q$ ) with converging setose pectinations. Head white; thorax white, black dotted. Fore wings white, silky, with a black dot on the cell and two superposed at the extremity of the cell; one below median vein at basal third and others at base suggesting a basal transverse line. A narrow blackish costal stripe and a terminal distinct interrupted line; fringes white. Hind wings smoky gray with whitish fringes. Beneath entirely blackish or smoky gray with a dark discal dot on hind wings. Abdomen smoky gray. Expanse 43 mil. Habitat, Colorado (Coll. E. L. Graef).

\section{Lygranthoecia acutilinea, $n$. s.}

o. Eyes naked, body slender, tibiæ armed. Form of marginata, Thoreaui and saturata. Ochrey or olive fuscous with snow white or silvery white lines. Transverse anterior greatly medially and outwardly exserted, preceded by a black marginal line, irregular, raggedly toothed. Cell shaded with whitish or pale ochrey. Reniform marked by black dots. Outer line denticulate, followed by a black line, crossed by white streaks on the median nervules. Subterminal line white, bent inwardly opposite the cell and again before internal margin. Fringes fuscous cut with white. Hind wings whitish with diffuse blackish discal spot and terminal band, the latter interrupted with white above anal angle. Fringes whitish, faintly interlineate. Beneath whitish, powdered with black; primaries blackish to exterior line with double black discal spots, the reniform open, fringes checkered; secondaries mostly whitish with black discal dot and whitish fringes; body pale fuscous. Expanse 27 mil. Habitat Colorado, Coll. E. L. Graef.

\section{Heliothis nuchalis Grote.}

This species is very near the European $H$. scutosa, as I find from a specimen of the latter in Mr. Graef's collection. As is the case with armiger and dipsacea, the American representatives of which I have described as umbrosus and phlogophagus, we have now a third species nearly related to the European. At the same time extended and careful comparisons of the American and European forms have not been entered into as yet with any of these species of Heliothis. 
Melicleptria oregonensis $\mathrm{Hy}$. Edw.

This species has been sent me by Dr. Bailey from Nevada (No. 19).

Chytoryza tecta Grote.

This genus is characterized by a pellucid impression on the fore wings of the male on the cell before the transverse posterior line. In the shape of the wings it differs from Pteraetholix bullula and in the thinner labial palpi. These two genera from Alabama and Texas seem to be our nearest allies to the genera Anomis and Aletia.

Catocala coulebs Grote.

Another specimen of this rare species has been taken by Mr. Hill this season in the Adirondacks. This species has the fore wings black and gray. What is probably a variety of $C$. badia, with brown primaries, but with the lines better marked than in the type, has passed erroneously as C. colebs in several collections I have recently seen. Probably this mistake has led to the belief that calebs was only a form of badia.

\section{Asopia cohortalis, n. s.}

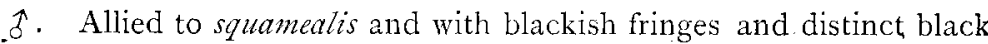
terminal line. Head and thorax, basal and terminal fields of primaries ochre brown. Median space shaded with black. Inner line dentate as in squamealis, black, preceded by a paler ochre shade. The pale shades are well marked on costa, but do not spread or form blotches as in squamealis. Outer line upright, a little bent in on costal region, denticulate, black; it is further removed from external margin than in squamtalis; between the lines are three costal marks; the two median lines are parallel, the distance between them remaining the same. Hind wings fuscous with double blackish lines; fringes interlined with black; a terminal black line; fringes fuscous. Beneath the primaries show a series of costal marks to the common outer line, which is black; beyond the line the terminal field is shaded with ochre. A dotted terminal black line; fringes fuscous, interlined. Expanse 25 mil. ; Colorado, Mr. E. L. Graef. The color and position of the outer line are different from squamealis.

Agrotis piscipellis, n. $s$.

$\delta$ q. A species with simple antennæ, armed tibiæ, naked eyes and untufted thorax, and somewhat flattened abdomen, which resembles Ufeus 
plicatus or some of the species of Homonadend," such as induta and incomitata. Thorax and fore wings dark but bright brown, veins more or less marked with black, stigmata obsolete, median lines sometimes obsolete, when present black, narrow, single; t. a. line upright, rivulous; t. p. line denticulate, exserted superiorly, marking venular points, followed by a faint pale shade; s. t. line pale. Hind wings pale at base, smoky outwardly, sub-pellucid, veins darker, no discal dot above or below. Front and tips of palpi very deep brown. Beneath pale, washed with reddish, a common black even line, veins indicated. Thorax and appendages and abdomen beneath rosy brown. Collar unlined. Expanse of 34 mil. (Colorado); +40 (Nevada); from Dr. James S. Bailey. May be placed with the albalis group, but resembles no species very nearly. Body not hairy as in $U$. plicatus.

\section{Agrotis cupida.}

This species seems to be subject to unusial variation. What may be taken as the typical form, or that which is best marked, expands $33-35$ mil, the wings are of a brick brown with the stigmata filled with black, a black mark on costa at inception of s. t. line, the s. t. space a little darker than the rest of the wing, the lines well defined. A larger form from 'Texas expands 40 mil. it has been reared from the larva by Belfrage (No. 674). It is more red, more unicolorous, the markings less obtrusive. A specimen taken by Dr. Bailey is the size of the typical form, but has the sub-basal and subterminal spaces entirely filled in with black. Then come three specimens in which the fore wings seem a little narrower and the expanse smaller. One is bright orange red, all the markings obsolete. Another is more of the typical shade, but both stigmata are ringed with bright yellow. The third I have described as distinct, under the name brumeipennis. This one, from Mr. Thaxter, is a little smaller than the others, expanding hardly over 30 mil. It is dark red-brown, almost immaculate. Whether these three belong to a different species from rupida remains doubtful.

Agrotis cupidissina.

It seems to me now probable that lactula is not sufficiently distinct from this Californian form. In the type of the latter the ground color is

* I can find no character to separate Mitalardona from this genus, to which I would accordingly refer $/$ T. atrifasiata (Morr.) 
darker, more purplish brown, while atpidissina is pale redclish clay color. But the powdery markings are the same in shape, and, bearing in mind the variation in cupida, it seems easy to include laetula as a form of cupidissima. At the same time the body seems slenderer in the type specimen I have, and the form more compact. These forms all have the collar unlined.

\section{Agrotis placida.}

A dark form with pale terminal space, but much smaller than alternata, which Mr. Hill has taken in the Adirondacks. Four specimens sent me from Nevada may be forms of this species. They all come from Dr. Bailey. One has the fore wings shaded with brown, median and terminal space both paler, markings quite distinct. Another is almost unicolorous blackish with the shadings and markings powdery. Again, another has a reddish cast reminding one of cupitar, but with pale terminal space. It does not seem possible that these Nevada specimens belong to distinct species, but for some time to come it is evident that our determinations in this group will be provisional unless we can find other characters than coloration and size to distinguish the "species."

\section{Agrotis alternata.}

A heavier form than cupida, the terminal space contrasting and paler. Varies much in tone; some specimens shaded with orange or reddish brown. Generally it seems of a clay color. One specimen from Nevada (Dr. Bailey) may be a distinct species. The median lines are more propinquitous and shaded with pale scales; the terminal space strongly contrasts. It is more likely, however, to be an extreme variety. Agrotis orbis from California may only be a form of alternata. I have a specimen from Colorado which seems intermediate, but which I refer to alternata provisionally. I have recently identified Glaea anchocelioides of Gueneé, which resembles some varieties of altemata, but has unarmed tibiæ.

Hadena senescens, $n . s$.

$\delta$ q. Male antennæ simple, ciliate; eyes naked, lashed. A tuft behind the collar and on the thorax behind. Tibia unarmed. Primaries straight along costal margin; wings rather broad. Pale dust color with the costal region to $s$. $t$. line of primaries shaded with brown. I.ines double. Orbicular oblique, narrow above, rounded below. Reniform large, pale with internal black annulus. Disc between the spots black. 
Subterminal space shaded with brown, showing the pale ante-apical dots distinctly. S. t. line marked with black before internal margin as in vigilans. A scalloped pale terminal line, interrupting the brown fringes. Hind wings blackish with pale terminal border and discal lunule. Beneath shaded with reddish ; dark discal lunules, double common shade lines, pale terminal border on both pair. Head and collar shaded with brown; pectus and legs blackish beneath; abdomen purplish-brown. Front and palpi blackish. Expanse $3^{6}$ mil. Taken by Mr. Hill in September in Lewis Co., N. Y. Allied to Hadena vigilans.

Hadena algens, n. s.

‥ Eyes naked, with lashes. Head not prominent but, as in vigilans and senescens, rather closely applied. Stone gray with inconspicuous markings. Collar pale with narrow black edging. A slight black basal dash. Lines and spots inconspicuous. Orbicular bordered on inside with black, edged with pale, subquadrate; reniform narrow, kidney-shape, both spots upright, incompletely edged with black and pale scales. S. t. line pale, irregular, marked with black on submedian fold. A terminal even dotted black line. Hind wings dark gray, reflecting the double lines and discal lunule of under surface. Beneath gray; discal spot of primaries open and nearly obsolete, on hind wings dark shade. The terminal space on both wings paler than rest of wing. Expanse zo mil. ; Maine, Prof. Fernald.

The three species here alluded to will be separated eventually from Hadena, but at the moment I refer them to the typical genus of the subgroup to which they belong.

Mamestra noiera, $n, s$.

$\delta$. Eyes hairy. Male antennæe simple. Fore wings of a mossy brownish olivaceous. Orbicular margined with black, open to costa, rounded, moderate. Reniform pale, elongate, subquadrate, erect. T. p. line double, pale centered, followed by points on the veins, outwardly oblique to vein 4 , thence inwardly oblique, nearly straight, below reniform to internal margin. Subterminal line pale, irregular, preceded and followed by black marks over the middle of the wing. Fringes concolorous, preceded by small black points and cut with pale. A black median basal dash or shading. Thorax concolorous; tegulæ shaded with blackish. Hind wings whitish at base with discal mark and broad smoky border. 
Beneath dusty gray with traces of double common lines and discal marks. Expanse 34 mil. Nebraska, Colorado, Dr. James S. Bailey. This species is allied to Goodellii, but it more closely resembles the following species, which, owing to the naked eyes, must be separated generically.

Hadena genitrix, n. s.

q. Eyes naked. This species is of a mossy blackish olivaceous with the ornamentation effaced. From the shape of the t. p. line, the position of the reniform and the excavation of hind wings, it is allied to curvata. Claviform outlined in part with black. Orbicular spherical, complete, somewhat widely separate from the pale, half-erect, rounded reniform, which is contiguous to the t. p. line. T. p. line pale-centered, double, lunulate, followed by pale points. S. t. line pale; fringes concolorous, cut with pale, preceded by black terminal dots. Hind wings entirely smoky with line and discal mark. Beneath pale, shaded with blackish on disc of fore wings; black discal points, distinct on secondaries and common lines; with sprinkled black scales on both wings. Thorax and head like primaries. Expanse 36 mil. Nebraska, Colorado, Nevada, Dr. James S. Bailey. The median lines are further apart than in $M$. noverca, the claviform is indicated, the reniform is somewhat oblique and lies against the $t$. p. line, which is more uneven than in $M$. noverca. The two species are liable to be confounded unless care is taken.

\section{Apatela theodori, n. s.}

d. Eyes naked; tibiæ unarmed. Gray shaded with pale brick red. Head and thorax above grayish, metathoracic tuft reddish : abdomen reddish gray. Fore wings gray with pale reddish shadings. Lines fine, black, single. Basal line arcuate. A fine black streak from base along submedian vein. The nervules also scantily marked with black scales. Sub-basal space shaded anteriorly with reddish. T. a. line slightly outwardly oblique, irregularly lunulate. Median shade marked in black on costa, commencing midway between the lines, greatly exserted medially, irregularly dentate, becoming reddish below costa. Median space before the shade gray, behind it reddish. Orbicular and claviform obsolete. Reniform reddish, large, undefined. T. p. line interspaceally dentate, rounded superiorly, thence inwardly oblique. Submedian space gray, except at costa, much invaded by the acutely and deeply dentate s. t. line which is preceded by black V-shaped shades, the one on submedian fold 
crossing the space and forming a dash. Terminal space reddish ; fringes interrupted. Hind wings white with faint mesial line, fringes white. Beneath white with reddish cast and faint reddish common line. Front with a black line. Expanse 43 mil. Colorado, Dr. Theodore S. Bailey, for whom I name the singularly colored species.

\section{MICRO-LEPIDOPTERA.}

BY V. T. CHAMBERS, COVTNGTON, KY.

PHILONOME.

Philonome Clemensella Chamb., ante v. 6, p. 97.

I have usually taken this species at the same place, about one or two specimens a year, and always within ten yards of the place where I first took it six years ago. The trees in the immediate vicinity were Gleditschio triacanthos, Ulmus americana, Prunus serotina and Celtis occidentalis, but it may have fed as larva upon some weeds or shrubs growing near. All of my specimens were taken about the 8th or roth of July. This year, however, I have captured (June I $4^{\text {th) }}$ ) two specimens (perfectly fresh) on Gleditschia triacanthos at another place, where the nearest tree was Celtis occidcntalis, growing some thirty yards away. Its larva and food plant, however, are not yet by any means certainly ascertained.

The labial palpi are divergent and ascending, and not quite so long as the maxillary pair. I have stated loc. cit. that the antennæ are about twothirds as long as the wing and pale reddish orange; perhaps it would be more correct to say that they are a little more than half as long as the wings, with the base reddish orange, and the stalk white tinged with pale orange or yellow. I have also stated that there is a reddish orange transverse stripe across the top of the thorax before its apex, and this is most 